\title{
Compliance with Best Practice Governance Principles by State Owned Enterprises in Botswana
}

\author{
Tebogo Israel Magang ${ }^{1} \&$ Koketso Bafana Kube ${ }^{2}$ \\ ${ }^{1}$ Department of Management, Faculty of Business; University of Botswana, Gaborone, Botswana \\ ${ }^{2}$ Adopt-A-Teen Youth Club, Botswana \\ Correspondence: Tebogo Israel Magang, Department of Management, Faculty of Business; University of \\ Botswana, Private Bag UB 00701, Gaborone, Botswana. E-mail: magangti@mopipi.ub.bw
}

Received: November 30, 2017

Accepted: January 5, 2018

Online Published: January 15, 2018

doi:10.5539/ijbm.v13n2p149

URL: ht tps://doi.org/10.5539/ijbm.v13n2p149

\begin{abstract}
This paper investigates the extent of compliance by 16 state owned enterprises (SOE)/parastatal corporations in Botswana with international best practice corporate governance principles. In particular the study examines the extent of compliance by SOEs with best practice corporate governance principles as recommended under the King Code of South Africa. The King Code (2002) of Corporate Governance is generally considered as a benchmark for best practice corporate governance not only in the Southern African region but also across the African continent.

Using a compliance checklist of 53 provisions from the Code, the study finds that $68.7 \%$ of Botswana SOEs have a compliance score of $51 \%$ and above while the remaining $31.3 \%$ applied less than $50 \%$ of the provisions in the King Code checklist. The study also finds that compliance with the Code increased from an average of $57 \%$ in 2009 to $60 \%$ in 2012. Further the study finds that SOEs tended to comply more with provisions on risk management and less on provisions on integrated sustainability reporting.

The results of this study have implications on governance practices of SOEs in Botswana in general. For instance, the results may possibly indicate that, even though governance structures of SOEs in Botswana are crafted through Acts of parliament, on the whole they adhere to international best practice corporate governance principles. The results could also be a signal to local and international investors that Botswana SOEs are not lagging behind in terms of compliance with good governance practices.
\end{abstract}

Keywords: Compliance, King Code, Corporate Governance, Parastatal Organisations/State Owned Enterprises

\section{Introduction}

State Owned Enterprises (SOEs) are semi-autonomous corporations set up by government through Acts of Parliament. They [SOEs/parastatals] are legal entities that work in relatively the same manner as private firms (Bozec, 2005, p. 1922; Magang \& Magang, 2016). However, the principal shareholder of the parastatal is the government and the board of directors of that parastatal reports to the Minister of the Government under whose portfolio, the SOE falls. They usually control key sectors such as agricultural exports, transport and telecommunications, manufacturing and agricultural trade. SOEs may be wholly owned by federal government or provincial government and are similar to private firms in the way they operate and function. Bozec (2005) argues that unlike public limited corporations, SOEs do not have major corporate governance (CG) control devices such as a market for corporate control and are normally monopolies. SOEs don't have shares issued to the public and are thus not exposed to pressure from the stock market (risk of takeover) (Bozec, 2005, p. 1929). They are financed wholly or in part from state resources, normally get the state as guarantor if funded from external sources, hence no pressure from creditors (Magang \& Magang, 2016). The funding for most parastatals is done through appropriations from parliament. In Botswana, when parastatal corporations faced bankruptcy, they sought financial bail-out from public coffers through parliament (Note 1).

SOE therefore occupy an important role in the socio-economic development of the country and are tasked with the responsibility of pursuing public policy, hence the need to prop them up with financial aid to avoid failure to deliver services to the public. Their affairs are subject to the scrutiny of parent Ministries and [ideally] through the Public Accounts Committee (Note 2). This places their responsibility to the Minister in charge of the ministry 
under which they fall. This scenario obtains in Botswana as is the case in other countries (developed and developing). In Botswana, Governance structures of SOEs are defined by the respective Acts of parliament which 'gave birth' to these corporations. For instance the Acts specifically define the composition of the board of directors of SOEs and that board appointments in SOEs are ultimately the prerogative of ministers under whose portfolio the respective SOE falls (Magang \& Magang, 2016). All the directors of SOEs are appointed (and removed) by the minister under whose portfolio the respective parastatal falls. The government exercises immense control over parastatals as the sole shareowner. As such, appointment of directors, chief executive officers, chairmen and other high ranking executives are the prerogative of ministers who head ministries which respective parastatal corporations fall under.

The Acts also specifically define the functions of respective boards of directors of SOEs. However, the Acts tend to limit the functions of the boards of directors to advisory and monitoring capacity. The Acts also specifically state that removal of board members from boards of directors is the prerogative of the Minister under whose portfolio the respective SOE falls. Some of the reasons cited across the various acts for removal include inter alia e.g. absence from (without reasonable cause) three consecutive meetings of the board, inefficiency, physical or mental incapability which may hinder a member from discharging their duties, contravention of the SOEs Act, unprofessional conduct as pronounced by relevant statutory bodies and failure to declare interests in accordance with respective sections of the Act(s) of the SOE (Magang and Magang, 2016).

The Acts place board control around the Minister(s) such that even director remuneration is subject to the approval by the Minister(s) under whose portfolio a SOE falls. Similarly, the boards of SOEs in Botswana do not have the leeway to appoint chief executive officers of SOEs/parastatals (Magang and Magang, 2016). Instead, the boards of directors may make recommendations to the respective Minister(s) as to whom the boards deems fit to occupy the position of CEO of the respective parastatal. However, the Minister(s) is not under an obligation to endorse this recommendation. As the appointing authority, the Minister(s) may also remove and or terminate the appointment of a CEO or director in a parastatal board under his/her portfolio. In a worst case scenario (from best practice corporate governance perspective) the Minister(s) is/are single handily empowered by the Act(s) to dissolve the entire board of directors of a SOE/parastatal. Reporting by SOEs is also made to the respective Minister(s) under whose portfolio the SOEs falls.

In light of the governance structures discussed above, this paper therefore seeks to investigate compliance with best practice corporate governance principles by parastatal corporations/SOEs in Botswana, as prescribed by the respective Acts of Parliament in comparison to the King Report (2002) of South Africa. The study specifically seeks to investigate the extent to which governance structures of SOEs in Botswana conform to international best practice. In a way this study is an extension of the study by Magang and Magang (2016) which investigated compliance with the King Code (2002) by Botswana Unified Revenue Services (BURS). In this study only one SOE was investigated for compliance with best practice corporate governance principles, whilst the proposed study covers several SOEs whose annual reports were available.

Specifically, this paper seeks to investigate whether the Botswana standard of corporate governance (as prescribed by Acts of Parliament) is at par or conforms to what is deemed international best practice using the King Code (2002) as the standard for international best practice. The results of the study may help Botswana legislators to craft (in future) $\mathrm{SOE} /$ parastatal Acts which conform to international best practice. This is important for the country owing to the importance of good governance more especially taking into account the fact that for a number of years Botswana has been battling to attract foreign direct investment. This aspect is even more important taking into account arguments advanced by Arthur Levitt (2000), former chairman of the US Securities \& Exchange Commission, that;

"If a country does not have a reputation for strong corporate governance practices, capital will flow elsewhere. If investors are not confident with the level of disclosure, capital will flow elsewhere. If a country opts for lax accounting and reporting standards, capital will flow elsewhere. All enterprises in that country suffer the consequences."

Source: https://www.sec.gov/news/speech/spch449.htm Speech by U.S. Securities \& Exchange Commission Chairman: Arthur Levitt, December 12, 2000

Botswana like many countries in the developed and developing world has not been spared with regard to corporate governance scandals. The country has had a share of governance scandals over the past decades; for instance politicians have for a number of years used the National Development Bank (NDB) (Note 3) as a vehicle to siphon money from public coffers by taking loans for agricultural purposes and later claiming to have made losses through farming and writing off the loans through a vote in parliament, something akin to 
institutionalised theft and or corruption (Good, 1994). Similarly in 1994, a report led by Kgabo uncovered illegal land-dealings in and around Mogoditshane a suburb of the capital city of Botswana, Gaborone. Governance scandals involving parastatals such as Botswana Housing Corporation (BHC) (Note 4) also surfaced in 1992 resulting in a report led by retired Judge Christie (Good, 1994), which identified 'gross mismanagement and dishonesty' in the BHC 'resulting in the loss of tens of millions of Pula' (Good, 1994, p. 504).

More recently, the local media has been awash with reports of allegations of bad governance in several of Botswana's SOEs/parastatals; for instance in Botswana Development Corporation (BDC) there were reports of incompetence at managerial and board level, financial fraud, money laundering, corruption in the awarding of multimillion Pula tender with respect to a multi-million Pula glass manufacturing plant in Palapye (Sunday Standard Reporter, 2011). In another SOE the Botswana Meat Commission (BMC) (Note 5), there were reports of poor corporate governance, conflict of interest by some board members, siphoning of money out of BMC and failure to adhere to strict standards set by the European Market (main market) resulting in delisting of BMC from lucrative European Markets (Boy, 2013; Khonani, 2015). According to the local press these allegations of maladministration, incompetence, fraud, theft, and corruption, resulted in huge losses of billions of Pula of public funds in the affected SOEs. It is in the context of these Botswana SOE shenanigans that the researchers seek to investigate corporate governance practices of parastatal organisations vis-a-vis international best practice (e.g. King Report, 2002).

Annual reports of parastatal organisations [subject to availability] were content analysed and scored though a self-constructed compliance checklist (developed from King II Report), to investigate the extent to which they embrace international best practice corporate governance.

The King Code II (2002) is considered appropriate for this investigation for the reasons stated by Magang and Magang (2016). For instance, Botswana only developed a code of corporate governance, the Botswana Code of Corporate Governance (BCCG) more recently in 2013. As such, the Code is beyond the scope of the study. Second, some of Botswana SOEs came into existence after the King Code of 1994 and 2002. As such parliamentarians could have bench marked against the King Code (2002) to craft governance structures of SOEs which conform to international best practice. The South African King Report is generally used as a standard for best practice corporate governance in Botswana. According to Magang and Magang (2016) several companies doing business in Botswana have their headquarters in South Africa. As such these companies are required by their head offices to adhere to the King Code of South Africa. Finally, the King Code is touted by researchers as the international best practice corporate governance standard (Mangena \& Chamisa, 2008). The King Code (2002) therefore qualifies as a standard for international best practice for the purposes of this study.

The rest of the document is organised as follows; the following section discusses the literature review and theoretical framework. Section 3 presents the research methods adopted for this study while section 4 presents the results. Finally in section 5 we provide a discussion and conclusion.

\section{Literature Review \& Theoretical Framework}

\subsection{Literature Review}

According to Bruton, Peng, Ahlstrom, Stan, \& Xu, (2015, p. 94), although inquiry into SOEs is on the rise there is still a dearth of research on the topic. Literature on corporate governance has historically been associated with the private sector, focusing on corporation-shareholder relationship, specifically in large and listed firms. For instance in Botswana Josiah et al., (2016) investigate the extent of compliance with Botswana Code of Corporate Governance (BCCG) (2013) by Botswana Stock Exchange (BSE) listed corporations and find that, while there is a high level of compliance with traditional principles of corporate governance e.g. board composition and separation of powers between the board chairperson and chief executive officer, there is limited compliance with contemporary governance principles such as governance of information technology and information security. The researchers also find that generally, the majority of BSE listed companies are yet to fully embrace the BCCG code. Overall, they document that most BSE listed corporations widely comply with the King Code, of South Africa. This finding further validates the use of the King Code as a standard bearer of best practice corporate governance in this study. The limitation with this study is that it focuses on listed corporations while the proposed study examines corporate governance practices of SOEs.

Others studies tend to focus on corporate governance and performance in SOEs. For instance an earlier study in Canada by Bozec (2005) examines boards of directors, market discipline and performance of 25 SOEs across industrial sectors for the period 1976 to 2000. Similarly more recent studies on corporate governance practices of SOEs (e.g. Berkman, Cole, \& Fu, 2014; Claessens \& Yurtoglu, 2013; Corrigan, 2014; Firth, Wong, \& Yang, 2014; Li, Lin, \& Selover, 2014; McGregor, 2011; Munisi, Hermes, \& Randøy, 2014; Ncube \& Maunganidze, 2014; 
Ponnu, 2008; Rouf, 2011; Sari, 2013; Zeng, Xu, Dong, \& Tam, 2010) tend to focus on governance structures of SOEs. In particular they investigate board of directors issues only, and do not investigate compliance by SOEs with best practice corporate governance principles as recommended by the respective codes. The aforementioned studies focus only on boards and directors issues only, while the proposed study examines other aspects of CG such as risk management, accounting and auditing and integrated sustainability reporting in addition to boards and directors issues.

However, a few recent studies have been conducted in the developing world to examine governance practices of SOEs/parastatals. For instance, Simpson (2013) investigates structures, attributes, and performance of boards of directors of state owned enterprises and finds that governance practices of SOEs in Ghana are still at an embryonic state as a result of existing regulatory frameworks establishing SOEs [also known as Acts of Parliament] and that regulatory bodies tasked with overseeing SOEs give minimal attention to corporate governance. Although this study examines governance structures of SOEs in a developing country, the results of the study may not be applicable to Botswana because of the socio-economic and political context of the two countries. Further, the current study examines compliance with the King Report (2002) which is considered to be the international best practice corporate governance standard (Mangena \& Chamisa, 2008) while the former used a local Ghanaian code. In a way, the current study examines compliance by SOEs with a code which has been tested.

In Botswana Magang and Magang (2016) investigate the extent of compliance with international best practice corporate governance principles by one SOE [e.g. Botswana Unified Revenue Service (BURS)]. Their study finds a low level of compliance with international best practice corporate governance principles as recommended by the King Report (2002). The results of the study suggest that Acts of Parliament in Botswana craft governance structures which fall below international best practice standard. Unlike Magang and Magang (2016) the current study examines compliance with the King Report (2002) by 16 SOEs over a four year period whilst the former examines compliance with best practice corporate governance by a single SOE. In addition, while Magang and Magang (2016) compares governance structure of one SOE with international best practice, the proposed study content analyses annual reports for the period in question to investigate the extent of compliance with international best practice principles. In a way, the proposed study fills the gap in the literature by examining corporate compliance with best practice CG by SOEs in Botswana. The findings of the study will give insights on governance standards and or practices of SOEs in Botswana.

\subsection{Theoretical Framework}

Conventional agency theory assumes a relationship or a contract (formal and informal, implicit and explicit) between two parties; principal and agent, shareholders and managers (Jensen \& Meckling, 1976; Ross, 1973), and managers and subordinates (Watts \& Zimmermann, 1978). Agency relationship results in divorce of ownership (principals) and control (agents), information asymmetry, goal conflicts and opportunistic behavior on the part of the contracting parties, especially the agent (Eisenhardt, 1989; Jensen \& Meckling, 1976; Noreen, 1988). As such, several mechanism have to be put in place to address agency problems e.g. Board of Directors (BODs) to perform oversight functions for the principals, i.e. monitor the agents. Researchers however question agency theory assumption that corporate managers are individualistic self-centered entities who serve their interests (e.g. Donaldson \& Davis, 1991; Mayer, Davis, \& Schoorman, 1995; Van Slyke, 2007). These researchers contend that corporate managers are team players, less prone to having individualistic goals and interests, and that they serve and are willing to work for the well-being of the larger group (e.g. Donaldson \& Davis, 1991; Mayer et al., 1995; Van Slyke, 2007).

According to the stewardship and stakeholder theorists, managers are good stewards who are motivated to work in the best interests of their principals. Donaldson and Davis (1991) argue that managers should be trusted, are pro-organisational, collectivistic and have higher utility than individualistic self-serving behaviours. However, findings from literature suggests that managers cannot be trusted, hence the need for monitoring and bonding (Deegan \& Unerman, 2006). The stakeholder theorists on the other hand see a corporate entity as a nexus of relationships. They view the organization as part of a broader social system wherein the organisation affects, and is affected by other groups within society (Clarkson, 1995; Donaldson \& Preston, 1995; Freeman \& Reed, 1983). The theory accepts that because various stakeholder groups will have divergent views about how an organisation should go about its operations, there will be various social contracts 'negotiated' with different stakeholder groups.

However, stakeholder theory has been critiqued for transforming "all and sundry into a stakeholder" (multiple accountability), for being incompatible with substantive business objectives and with corporate governance (Key, 
1999; Sternberg, 1999, p. 13).

Agency relationships in a SOE/parastatal are defined by a long chain of delegation between principals and the agents (Magang \& Magang, 2016; StrØm, 2000). Accountability between the actual principals and agents is therefore indirect. In the case of Botswana parliamentary democracy, the parliamentarians are the direct agents of the people/electorate who are also referred to as principals; the legislators then delegate to the executive branch in particular to the head of government (president); the third line of delegation is from the president to heads of different executive departments (ministers) and finally from heads of different executive departments to civil servants (Steffani, 1979 cited in StrØm, 2000, p. 267) who ultimately have the responsibility to implement public policy (StrØM, 2000).

Agency theory (Berle \& Means, 1932) maintains that any delegation of authority from principal to agent creates the risk that the agent may not faithfully pursue the interests of the principal. If the agent has interests and incentives that are not perfectly compatible with those of the principal, delegation may generate agency problems which leads to agency losses.

In the case of SOEs the chain of delegation is such that shareholders (the electorate/general public) do not have a direct relationship with the management of SOEs because SOE managers report to the Minister under whose portfolio the SOE falls (Magang \& Magang, 2016; StrØm, 2000). This takes away the conventional power of removing non-performing directors at annual general meetings (AGM) through a shareholders' vote as is the case under public limited corporations. Further, the long chain of delegation under a system of parliamentary democracy creates [or has the potential] the following scenarios; (1) agents (SOE management) who owe their allegiance to agents (ministers who appointed them to directorship positions); (2) unavailability of mechanisms to sanction non-performing directors because board appointments are the prerogative of the minister; (3) weak boards which are controlled by the appointing authority (minister) (4) a chief executive officer (CEO) who does not answer to the board of directors because he is appointed and may only be removed by the minister; (5) appointment to board of directors based on patronage (e.g. friendship, tribe mate or even paramours) and not skill and competence; (6) incompetence, corruption, nepotism, poor accountability, lack of independence, influence by politicians, a culture of payment of facilitation fees [bribes] among others (Tebogo Israel Magang \& Magang, 2016; Okeahalam, 2004). Ultimately, this may result in weak boards which fail to discharge their oversight function. Weak boards may result in weak institutions which fail to achieve organisational objectives. Organisational objectives in the case of SOEs may mean provision of clean drinking water, electricity, health care facilities, telecommunication services, building of roads, educational services, policing services, security etc (Magang and Magang, 2016).

In the light of challenges resulting from the long chain of delegation in SOEs, it is therefore interesting to investigate the extent to which SOEs comply with international best practice corporate governance principles as recommended under the King Code (2002). As such, both agency theory and stakeholder theory are used to explain the relationships between the variables under investigation.

\section{Research Methods}

This descriptive study was conducted in Botswana among 16 SOEs whose annual reports were obtained for the years 2009 and 2012. The researchers began by drawing a list of all SOEs organisations in Botswana. Secondly SOEs which were established after 2012 were excluded as well as those without annual reports for the years 2009, 2010, 2011 and 2012. Following the set criteria, only 16 parastatals were chosen to be used in the study (see Appendix A; List of Parastatals Included in the Study). The researchers physically visited parastatal organisations to request for annual reports for the period under investigation. In some instances the annual reports were available on the web pages of some parastatal organisations. Companies may use other medium of communication to communicate adherence to best practice corporate governance (Haniffa \& Cooke, 2005). Similar to prior literature (e.g. Haniffa \& Cooke, 2005; Ntim, Opong, Danbolt, \& Thomas, 2012) this study relies on annual reports because of the high credibility attached to disclosures in these reports (Haniffa and Cooke, 2005). Prior literature also indicates that annual reports are used by stakeholders as the sole source of information (Haniffa and Cooke, 2005) and that they "offer a snapshot of management's mindset in a particular period" (Haniffa \& Cooke, 2005, p. 404; Neimark, 1992). Researchers also argue that annual reports are more accessible for research purposes (Haniffa and Cooke, 2005).

In accordance with prior literature (Gompers, Ishii, \& Metrick, 2003; Magang \& Magang, 2016; Ntim et al., 2012) a self-constructed checklist consisting of 53 items (see Appendix B; South African King Code Checklist (SAKCC) from the King Code II was developed to investigate the level of application of the provisions of the Code. The checklist was segmented into four sections in accordance with the following themes; Board of 


\section{Directors, Risk Management, Accounting \& Auditing and Integrated Sustainability Reporting.}

The content analysis method of codifying written texts into various categories was used to collect the compliance data (Hackston and Milne, 1996). Key words were used to search the content of annual reports for best practice corporate governance principles complied with/applied by parastatal corporations for the period under study. Companies were scored as "1" complied with or "0" otherwise. Similar to Ntim (2009); and Magang, (2012), where explanations were proffered as to why companies did not apply a specific provision a score of " 1 " was given.

The scores were aggregated to determine the percentage of items complied with or applied by respective SOEs (Average Compliance Index or ACI). Similar to Magang (2012) and Ntim (2009) a SOE is considered to comply with international best practice if its $\mathrm{ACI}$ is $51 \%$ and above.

\section{Descriptive Analysis of SOEs}

Table 1, Industry Type, Average Total Assets and Auditor Rotation presents an analysis of SOEs in terms of industry type, average capitalisation and auditor rotation over the period under review. The largest institution in terms of total assets is the Bank of Botswana (BOB) and the smallest in terms of average total assets is NBFIRA. Results from Table 1 also indicate that only four SOEs rotated their auditors during the period under review e.g. BOB, NDB and the BSE. All the other SOEs retained the same auditors for the period under review.

Table 1. Industry Type, Average Total Assets and Auditor Rotation

\begin{tabular}{llll}
\hline SOE & Industry Type & Average Cap (4 Year) (P) & Auditor Rotation \\
\hline NBFIRA & Regulatory & $6,950,049$ & No \\
PPADB & Regulatory & $9,717,726$ & No \\
BSE & Stock Exchange & $17,826,833$ & Yes \\
BIDPA & Research Institute & $24,744,102$ & No \\
BAMB & Agriculture & $167,708,661$ & Yes \\
BOCRA & Regulatory & $247,436,298$ & No \\
Botswana Post & Postal Services & $306,749,242$ & No \\
CEDA (Note 7) & Financial & $1,066,678,824$ & No \\
NDB & Financial & $1,086,806,750$ & Yes \\
BTC & Telecommunications & $1,953,050,500$ & No \\
BBS & Financial & $2,070,768,250$ & No \\
BHC & Real Estate & $2,302,361,000$ & No \\
MVAF & Insurance & $2,329,971,815$ & No \\
BDC & Commercial \& Industrial & $2,952,280,500$ & No \\
BPC & Utility & $12,137,470,000$ & No \\
BOB & Financial & $57,740,756,000$ & Yes \\
\hline
\end{tabular}

The issue of auditor rotation is still contentious amongst governance pundits. There are those who argue against auditor rotation and those who argue for auditor rotation. Proponents of auditor rotation maintain that independence of auditors is undermined by long terms of appointment as risks arise from close association and over familiarity. As such, complacency could arise and this may adversely affect the auditor's independence and reduce the reliability and quality of the audit (Gates, Lowe, \& Reckers, 2006, p. 5; Howarth, 2012). They also argue that auditor rotation may open up the open market and provide an opportunity for more firms to engage in the audits of public interest entities (Howarth, 2012; The Institute of Internal Auditors, 2012). There are also arguments that the existing auditor would know that any errors or omissions could be discovered by an ensuing auditor.

Opponents of auditor rotation on the other hand maintain that, rotation is costly and disruptive and could undermine audit quality (Howarth, 2012). They also argue that it is advantageous to keep auditors that are familiar with the business and who have been reappointed by management with the support of investors. It is also argued that fixed term appointments for auditors could result in auditors not investing in building their knowledge in the auditee for the long term, and focussing on profit at the expense of quality. Further, mandatory audit rotation may result in; the need for auditors to frequently spend time and money to familiarise themselves with complex operations of their new clients resulting in a significantly higher audit fees as firms pass on the 
cost to their clients. Also audit quality may be greatly reduced during the start up period (Howarth, 2012; Pozen, 2012; The Institute of Internal Auditors, 2012).

In the wake of the Enron/Athur Anderson scandal of 2001, the Sarbanes-Oxley (SOX) Act in the US required audit partner rotation every 5 years for publicly held companies. This provision only applies to the lead auditor and the auditor responsible for reviewing the audit, not the auditing firm.

King Code (2002) and subsequent Codes (e.g. King IV, 2017) acknowledge the need to assess and confirm the external auditor's independence, but do not specifically address audit firm rotation. King IV Code suggests that the audit committee oversees auditor independence. However, the number of years for which the audit firm has been the auditor of the company be disclosed in the auditor's report. In addition, the audit committee must disclose any significant audit matters considered and how the committee has addressed the matters (King IV, 2017).

In this regard, the Botswana SOEs have to a great extent complied with international best practice with regard to auditor independence as evidenced from disclosures in the annual reports for the period under review.

\section{Compliance Results}

\subsection{Overall Compliance with the Code Provisions}

Table 2; Overall King Code Compliance Results, presents the results of overall compliance and or application of 53 items from the checklist. The table gives the total compliance for each Botswana SOE for the four year period under investigation and the average compliance for the four year period for each company. As per results from Table 2, average compliance with provisions from the Code has increased over the four year period from $57 \%$ to $60 \%$. This trend is also evident for individual companies.

Table 2. Overall king code compliance checklist

\begin{tabular}{llllll}
\hline Parastatal & 2009 & 2010 & 2011 & 2012 & Average \\
\hline BAMB & 53 & 55 & 55 & 61 & 56 \\
BBS & 43 & 41 & 41 & 41 & 42 \\
BDC & 82 & 84 & 84 & 84 & 84 \\
BHC & 73 & 73 & 73 & 73 & 73 \\
BIDPA & 39 & 39 & 39 & 39 & 39 \\
BOB & 41 & 41 & 41 & 49 & 43 \\
BP & 49 & 59 & 69 & 72 & 62 \\
BPC & 58 & 61 & 61 & 61 & 60 \\
BSE & 65 & 65 & 65 & 74 & 67 \\
BTA & 69 & 76 & 76 & 76 & 74 \\
BTC & 84 & 84 & 86 & 86 & 85 \\
CEDA & 53 & 51 & 53 & 53 & 53 \\
MVAF & 59 & 73 & 76 & 75 & 71 \\
NBFIRA & 61 & 61 & 63 & 65 & 63 \\
NDB & 33 & 37 & 43 & 41 & 39 \\
PPADB & 59 & 63 & 63 & 63 & 62 \\
& & & & & \\
Average & $\mathbf{5 7}$ & $\mathbf{5 9}$ & $\mathbf{6 1}$ & $\mathbf{6 2}$ & $\mathbf{6 0}$ \\
\hline
\end{tabular}

This trend indicates that over the four year period Botswana SOEs have been embracing international best practice corporate governance principles possibly because of incidences of allegations of maladministration reported in the print media during this period e.g. the Palapye glass project debacle (Sunday Standard Reporter, 2011).

The results further indicate that $31.3 \%$ (5) of the SOEs failed to achieve an average compliance index (ACI) of $50 \%$, while $68.7 \%$ (11) of the SOEs in the sample archived an ACI of $51 \%$ or more. As such the results indicate that $31.3 \%$ of the companies in the sample failed to comply with the provisions of the King Code (2002) in the checklist while $70.6 \%$ demonstrated satisfactory level of compliance.

Three companies achieved an ACI in the region of $70 \%$ to $79 \%$. The results also indicate that only BDC and BTC achieved an ACI of $80 \%$ and more. Results from Table 2 also indicate that NBFIRA registered the lowest 
$\mathrm{ACI}$ (at 38.5\%) while BTC registered the highest ACI at $85 \%$ level of compliance with provisions from the King Code.

BDC and BTC are relatively old companies which have been in the business for a number of decades (e.g. over 45 years and 35 years respectively). As such, the companies have been under scrutiny for these number of years which has enabled them to enhance their corporate governance practices. In comparison NBFIRA came into existence through an Act of Parliament in 2006 (e.g. The Non-Bank Financial Institutions Regulatory Act, 2006). The company is still at its infant stages hence learning the ropes of best practice corporate governance.

\subsection{Average Compliance with Boards and Directors Provisions}

Table 3: Compliance with Board and Directors, presents results on compliance with code provisions pertaining to boards and directors issues. According to results from Table 3,37.5\% (6) of the SOEs in the sample failed to comply with $50 \%$ of the provisions under this theme while $62.5 \%$ (11) complied with the provisions under this theme.

Table 3. Compliance with board and directors

\begin{tabular}{llllll}
\hline Parastatal & 2009 & 2010 & 2011 & 2012 & Average \\
\hline BAMB & 60 & 60 & 60 & 60 & 60 \\
BBS & 37 & 33 & 33 & 33 & 34 \\
BDC & 77 & 77 & 77 & 77 & 77 \\
BHC & 73 & 73 & 73 & 73 & 73 \\
BIDPA & 27 & 27 & 27 & 27 & 27 \\
BOB & 33 & 33 & 33 & 47 & 37 \\
BP & 60 & 73 & 73 & 73 & 70 \\
BPC & 47 & 50 & 50 & 50 & 49 \\
BSE & 70 & 70 & 70 & 77 & 72 \\
BTA & 63 & 77 & 77 & 77 & 74 \\
BTC & 77 & 77 & 80 & 80 & 79 \\
CEDA & 57 & 77 & 80 & 80 & 74 \\
MVAF & 60 & 60 & 60 & 60 & 60 \\
NBFIRA & 23 & 30 & 30 & 37 & 30 \\
NDB & 63 & 67 & 67 & 67 & 66 \\
PPADB & 43 & 40 & 40 & 37 & 40 \\
Average & $\mathbf{5 4}$ & $\mathbf{5 8}$ & $\mathbf{5 8}$ & $\mathbf{6 0}$ & $\mathbf{5 7}$ \\
\hline
\end{tabular}

The results from Table 2 also indicate that BIDPA registered the lowest ACI with boards and directors issues at $27.0 \%$ while BTC registered the highest ACI at $78.5 \%$. BIDPA is a research institute with an average asset base of just over P24 Million for the ensuing period. It has been in operation since 1995. Its vision/mission statement is "to be a centre of excellence that provides policy research, analysis, advice and capacity building" (BIDPA, 2017). BIDPA's work may not necessarily attract scrutiny from the public (e.g. media, and other agencies) the organisation's activities are generally abstract/intellectual as such do not translate into immediate tangible results on the ground. Unlike large firms, small firms do not have to seek legitimacy between their actions and the values of general and relevant publics (Dowling \& Pfeffer, 1975; Lindblom, 1994) because they are not visible in the public eye and less politically sensitive (Watts \& Zimmermann, 1978). Large firms like BTC are subject to scrutiny and to greater political and regulatory pressure from external interests (Belkaoui \& Karpik, 1989). Unlike small firms, large firms face scrutiny by the media and may suffer bad publicity, loss of business and the imposition of more regulations following non-compliance than smaller firms (Dedman, 2000). This may therefore explain why BTC complies more with best practice corporate governance principles than small firms like BIDPA.

Also, compliance for BTC may be high for the period under review because as a large firm BTC has more analysts following than smaller firms like BIDPA (Lang \& Lundholm, 1993; McKinnon \& Dalimunthe, 1993) and therefore may feel the need to adhere to good CG practices such as the King Code to signal to analysts, financiers and regulatory bodies that they are compliant with best practice governance principles.

\subsection{Average Compliance with Risk Management Provisions}


Compliance with provisions from this theme as per results from Table 4: Compliance with Risk Management Provisions indicate that, $25 \%$ (4) of parastatals corporations in the sample failed to comply with $50 \%$ of Code provisions under this theme while 75\% (12) complied with provisions from this theme.

Table 4. Compliance with Risk Management Provisions

\begin{tabular}{llllll}
\hline Parastatal & $\mathbf{2 0 0 9}$ & $\mathbf{2 0 1 0}$ & $\mathbf{2 0 1 1}$ & $\mathbf{2 0 1 2}$ & Average \\
\hline BAMB & 33 & 33 & 33 & 67 & 42 \\
BBS & 67 & 67 & 67 & 67 & 67 \\
BDC & 100 & 100 & 100 & 100 & 100 \\
BHC & 89 & 89 & 89 & 89 & 89 \\
BIDPA & 67 & 67 & 67 & 67 & 67 \\
BOB & 67 & 67 & 67 & 67 & 67 \\
BP & 56 & 56 & 78 & 89 & 70 \\
BPC & 67 & 78 & 78 & 78 & 75 \\
BSE & 78 & 78 & 78 & 78 & 78 \\
BTA & 89 & 89 & 89 & 89 & 89 \\
BTC & 100 & 100 & 100 & 100 & 100 \\
CEDA & 78 & 78 & 78 & 78 & 78 \\
MVAF & 56 & 56 & 56 & 67 & 59 \\
NBFIRA & 44 & 44 & 67 & 44 & 50 \\
NDB & 44 & 56 & 56 & 56 & 53 \\
PPADB & 22 & 22 & 22 & 22 & 22 \\
Average & $\mathbf{6 6}$ & $\mathbf{6 8}$ & $\mathbf{7 0}$ & $\mathbf{7 2}$ & $\mathbf{6 9}$ \\
\hline
\end{tabular}

The results also indicate that the average compliance over the four year period of PPADB was the lowest at $22.0 \%$ of provisions from the Code under this theme while BTC and BDC complied with all the provisions under this theme from the Code $(100 \%)$ over the four year period. PPADB like other small firms in its category may not be having a large following by analysts (Lang \& Lundholm, 1993; McKinnon \& Dalimunthe, 1993) like large firms. As such, the firm may not be under pressure to comply with best practice corporate governance principles.

\subsection{Average Compliance with Accounting and Auditing Provisions}

Table 5: Compliance with Accounting and Auditing Provisions presents results from compliance with provisions under Accounting and Auditing theme. The results indicate that only $12.5 \%$ (2) parastatal corporations failed to comply with half of the provisions under this theme while $87.5 \%$ (14) parastatal corporations complied with more than $50 \%$ of the provisions under this theme.

Table 5. Compliance with Accounting and Auditing Provisions

\begin{tabular}{llllll}
\hline Parastatal & $\mathbf{2 0 0 9}$ & $\mathbf{2 0 1 0}$ & $\mathbf{2 0 1 1}$ & $\mathbf{2 0 1 2}$ & Average \\
\hline BAMB & 67 & 67 & 67 & 67 & 67 \\
BBS & 67 & 67 & 67 & 67 & 67 \\
BDC & 67 & 67 & 67 & 67 & 67 \\
BHC & 67 & 67 & 67 & 67 & 67 \\
BIDPA & 67 & 67 & 67 & 67 & 67 \\
BOB & 33 & 33 & 33 & 33 & 33 \\
BP & 33 & 67 & 67 & 67 & 59 \\
BPC & 67 & 67 & 67 & 67 & 67 \\
BSE & 67 & 67 & 67 & 67 & 67 \\
BTA & 89 & 89 & 89 & 89 & 89 \\
BTC & 67 & 67 & 67 & 67 & 67 \\
CEDA & 67 & 67 & 67 & 67 & 67 \\
MVAF & 67 & 67 & 67 & 67 & 67 \\
NBFIRA & 33 & 33 & 33 & 33 & 33 \\
NDB & 67 & 67 & 67 & 67 & 67 \\
PPADB & 67 & 67 & 67 & 67 & 67 \\
Average & $\mathbf{6 2}$ & $\mathbf{6 4}$ & $\mathbf{6 4}$ & $\mathbf{6 4}$ & $\mathbf{6 4}$ \\
\hline
\end{tabular}


Compliance under this theme was generally high for all the SOE companies. This was expected given that accounting and auditing provisions are what researchers call traditional principles of corporate governance (e.g. Josiah et al., 2016). Surprisingly, the results indicate that BOB (central Bank of Botswana) applied only $33.0 \%$ of provisions from the Code under this theme while BTC applied $89.0 \%$ of the provisions under this theme from the Code. BOB is the central Bank of Botswana which does not conform to two provisions (out of three) which are generally deemed traditional corporate governance principles such as disclosing amount paid to external auditors and reporting on the description of non-audit services rendered by the external auditor.

\subsection{Average Compliance with Integrated Sustainability Reporting Provisions}

Table 6: Compliance with Integrated Sustainability Reporting Provisions presents results from compliance with provisions under Integrated Sustainability Reporting Provisions theme. The results indicate that only $37.5 \%$ (6) parastatal corporations failed to comply with half of the provisions under this theme while $62.5 \%$ (10) parastatal corporations complied with more than $50 \%$ of the provisions under this theme.

Table 6. Compliance with Integrated Sustainability Reporting Provisions

\begin{tabular}{llllll}
\hline Parastatal & $\mathbf{2 0 0 9}$ & $\mathbf{2 0 1 0}$ & $\mathbf{2 0 1 1}$ & $\mathbf{2 0 1 2}$ & Average \\
\hline BAMB & 43 & 57 & 57 & 57 & 54 \\
BBS & 29 & 29 & 29 & 29 & 29 \\
BDC & 86 & 100 & 100 & 100 & 97 \\
BHC & 57 & 57 & 57 & 57 & 57 \\
BIDPA & 43 & 43 & 43 & 43 & 43 \\
BOB & 43 & 43 & 43 & 43 & 43 \\
BPC & 0 & 0 & 43 & 43 & 22 \\
BPC & 86 & 86 & 86 & 86 & 86 \\
BSE & 29 & 29 & 29 & 58 & 36 \\
BTA & 71 & 57 & 57 & 57 & 61 \\
BTC & 100 & 100 & 100 & 100 & 100 \\
CEDA & 43 & 57 & 57 & 57 & 54 \\
MVAF & 71 & 71 & 86 & 86 & 79 \\
NBFIRA & 57 & 57 & 71 & 57 & 61 \\
NDB & 57 & 57 & 57 & 57 & 57 \\
PPADB & 57 & 57 & 57 & 57 & 57 \\
Average & $\mathbf{5 5}$ & $\mathbf{5 6}$ & $\mathbf{6 1}$ & $\mathbf{6 2}$ & $\mathbf{5 8}$ \\
\hline
\end{tabular}

BPC complied less with provisions under integrated sustainability reporting at $21.5 \%$ of code provisions compared to BTC which complied with all the provisions (100.0\%) under this theme. Integrated sustainability reporting consists of social and environmental reporting provisions. Prior studies on compliance with beast practice by listed JSE corporations finds less compliance with social and environmental reporting (integrated sustainability reporting) in comparison to other key issues (e.g. Magang, 2012). BPC was found to be the least compliant firm under this theme. It is surprising to note that BPC which uses coal powered power plants to generate electricity complies less with environmental issues. Emissions that result from combustion of fossil fuels such as coal include Carbon dioxide (CO2), Carbon monoxide (CO), Sulfur dioxide (SO2), Nitrogen oxides (NOx) etc which have negative impacts on the environment and human health. For instance, $\mathrm{CO} 2$ is a greenhouse gas, which contributes to the greenhouse effect, $\mathrm{SO} 2$ causes acid rain, which is harmful to plants and to animals that live in water. $\mathrm{SO} 2$ also worsens respiratory illnesses and heart diseases, particularly in children and the elderly and NOx contribute to ground level ozone, which irritates and damages the lungs. It is therefore surprising to note that a power utility with carbon footprints like BPC is not doing enough to mitigate the harmful effects of its activities on the environment. BPC is a monopoly which produces electricity for Botswana and wholly owned by the state. Perhaps the company is not subject to stringent regulatory requirements [from Government Regulatory Agencies] which may explain its laxity in compliance with social and environmental issues.

\section{Summary of Compliance Results}

This section provides a summary of the results of compliance with the King Code provisions. As per results from Table 7: Summary of Results of Code Provisions, the highest level of compliance with the Code provisions were registered under integrated sustainability reporting and risk management at $100 \%$ level of compliance for both 
provisions.

Table 7. Summary Results of Code Provisions

\begin{tabular}{lll}
\hline Compliance Theme & Parastatal & Percentage \\
\hline Total Compliance & & \\
Lowest & NBFIRA & 38.5 \\
Highest & BTC & 85.0 \\
Board \& Directors & & \\
Lowest & BIDPA & 27.0 \\
Highest & BTC & 78.5 \\
Risk Management & & \\
Lowest & PPADB & 22.0 \\
Highest & BTC & 100.0 \\
Accounting \& Auditing & & \\
Lowest & BOB & 33.0 \\
Highest & BTA & 89.0 \\
Integrated Sustainability Reporting & & \\
Lowest & BPC & 21.5 \\
Highest & BTC & 100.0 \\
\hline
\end{tabular}

It is also interesting to note that the lowest level of compliance was registered under the two provisions (risk management and integrated sustainability reporting) at $21.5 \%$ (by BPC) and $22.0 \%$ (by PPADB) level of compliance respectively. The results also indicate that BTC, a telecommunications corporation, registered the highest level of total compliance with all the code provisions. BTC also registered the highest level of compliance in three provisions of the Code, thus; boards and directors, accounting and auditing and integrated sustainability reporting.

Table 8: presents a comparison of analysis of average compliance for the four provisions and the average for the total compliance for the four year period under review. Generally the results indicate that compliance with Code provisions has been increasing over the four year period for each provision except for accounting and auditing which has been stagnant at an average level of compliance of $64 \%$.

Table 8. Average compliance for king code provisions

\begin{tabular}{llllll}
\hline Provision & 2009 & 2010 & 2011 & 2012 & Average \\
\hline Total Compliance & 57 & 59 & 61 & 62 & 59.8 \\
Boards \& Directors & 55 & 58 & 58 & 60 & 57.8 \\
Risk Management & 65 & 66 & 69 & 71 & 67.8 \\
Accounting \& Auditing & 62 & 64 & 64 & 64 & 63.5 \\
Integrated Sustainability Reporting & 54 & 55 & 59 & 60 & 57.0 \\
\hline
\end{tabular}

Results from Table 8 indicate that the average compliance with the risk management provision was the highest across the four year period under investigation. The results also indicate that risk management and integrated sustainability reporting registered the highest increase in level of compliance of $6 \%$ between the years 2009 and 2012 compared to accounting and auditing which registered only $2 \%$ increase for the same period.

\section{Discussion/Conclusion}

We investigate through a descriptive study, whether the Botswana standard of corporate governance (as prescribed by Acts of Parliament) is at par or conforms to what is deemed international best practice using the King Code (2002) as the benchmark for international best practice. Using a checklist of 53 provisions [the SAKCC], to score annual reports of 16 SOEs, the study finds that generally SOEs in Botswana comply with international best practice corporate governance principles (e.g. King Report, 2002). The results of the study indicate that compliance with code provisions has on average been gradually increasing for the 16 SOEs from $57 \%$ to $62 \%$ between 2009 and 2012 respectively.

These findings are in contrast to Magang and Magang (2016) who find a low level of conformance to 
international best practice by BURS, in their study to investigate whether governance structure of BURS conform to international best practice corporate governance principles as recommended by the King Code (2002). This study (Magang and Magang, 2016) however, focussed on the boards and directors issues hence why the contrast in the findings whilst the current study examined compliance with 53 King Code provisions by 16 Botswana SOEs. The findings are however, consistent with Josiah et al. (2016) who report a high level of compliance with traditional principles of corporate governance such as board composition and separation of powers between the board chairperson and the chief executive officer by Botswana Stock Exchange listed corporations. However, we hasten to add that unlike SOEs exchange listed corporations have major corporate governance (CG) control devices such as a market for corporate control, are constantly under scrutiny from the investing public, the media and have to comply with a raft of regulations from the stock exchange. As such, compliance with best practice corporate governance principles is expected to be high among stock exchange listed corporations versus SOEs.

The results also contradict the theoretical argument that the long chain of delegation of authority from principal to agent [in SOEs] creates the risk that the agent may not faithfully pursue the interests of the principal. The findings seem so support the theoretical argument that managers [of SOEs] are good stewards who are motivated to work in the best interests of their principals (Donaldson and Davis, 1991). The results lend support to Donaldson and Davis (1991) contention that managers should be trusted, are pro-organisational, collectivistic and have higher utility than individualistic self-serving behaviours, hence compliance with best practice corporate governance by Botswana SOEs.

The results also portray a positive image on the Botswana SOEs with regard to adhering to international best practice corporate governance principles such as the King Report of South Africa. The findings of the study could be a signal to local and international investors that Botswana is a safe and suitable destination for investment capital. However, these results relate to the period 2009 to 2012 which was characterised by allegations of corruption and maladministration in Botswana SOEs (Sunday Standard Reporter, 2011). Also, the results of this study are based on assertions in annual reports by management of SOEs. As such, disclosures in annual reports may not necessarily reflect the true practice in the SOEs. For instance, while annual reports indicate adherence to international best practice corporate governance principles such as the King Report, corporate managers may on the other hand [in practice] be engaging on massive corporate fraud, mismanagement, corruption etc.

This study is limited in the sense that it only covered a four year period. Future research, could conduct a longitudinal investigation of governance practices of all SOEs in Botswana covering recent years to determine whether good governance practices have continued to improve among Botswana SOEs. Future research could also investigate governance structures of other SOEs across the Southern African Development Community (SADC) region to determine whether they conform to international best practice corporate governance principles and make comparisons across the SADC region. Finally, future research could also adopt a different approach to investigating compliance with best practice corporate governance principles by Botswana SOEs.

\section{References}

Belkaoui, A., \& Karpik, P. G. (1989). Determinants of the Corporate Decision to Disclose Social Information. Accounting, Auditing \& Accountability Journal, 2(1), 36-51. https://EconPapers.repec.org/RePEc:eee:jappol:v:2:y:1983:i:3:p:207-219

Berkman, H., Cole, R. A., \& Fu, L. J. (2014). Improving corporate governance where the State is the controlling block holder: Evidence from China. The European Journal of Finance, 20(7-9), 752-777. https://doi.org/10.1080/1351847X.2012.671784

Berle, A. A., \& Means, C. G. (Eds.). (1932). The Modern Corporation and Private Property (New York: Harcourt, Brace \& World.

Boy, R. (2013). Cattle Traceability-A Threat to Sustainable Supply of Beef to EU; A Botswana Meat Commission Case Study. European Journal of Logistics Purchasing and Supply Chain Management, 1(1), $1-9$.

Bozec, R. (2005). Boards of Directors, Market Discipline and Firm Performance. Journal of Business Finance \& Accounting, 32(9-10), 1921-1960. https://doi.org/10.1111/j.0306-686X.2005.00652.x

Bruton, G. D., Peng, M. W., Ahlstrom, D., Stan, C., \& Xu, K. (2015).State-owned enterprises around the world as hybrid organizations. Academy of Management Perspectives, 29(1), 92-114. https://doi.org/10.5465/amp.2013.0069 
Claessens, S., \& Yurtoglu, B. B. (2013). Corporate governance in emerging markets: A survey. Emerging markets review, 15, 1-33. https://EconPapers.repec.org/RePEc:eee:ememar:v:15:y:2013:i:c:p:1-33

Clarkson, M. (1995). 'A stakeholder framework for analyzing and evaluating corporate social performance'. Academy of Management Review, 20(1), 92 - 118. https://doi.org/10.5465/AMR.1995.9503271994

Corrigan, T. (2014). Corporate Governance in Africa's State-owned Enterprises: Perspectives on an Evolving System. SAIIA Policy Briefing, (102).

Dedman, E. (2000). An Investigation into the Determinants of UK Board Structure Before and After Cadbury. Corporate Governance, 8(2), 133-153. https://doi.org/10.1111/1467-8683.00191

Deegan, C., \& Unerman, J. (Eds.). (2006). Financial Accounting Theory. UK: McGraw Hill.

Dipholo, K. (2015). The Public Accounts Committee is as Hopeless and Pretentious as Parliament. http://www.sundaystandard.info/public-accounts-committee-hopeless-and-pretentious-parliament

Donaldson, L., \& Davis, J. H. (1991). Stewardship Theory or Agency Theory: CEO Governance and Shareholder Returns. Australian Journal of Management, 16(1), 49-64. https://doi.org/10.1177/031289629101600103

Donaldson, T., \& Preston, L. E. (1995). The Stakeholder Theory of the Corporation - Concepts, Evidence, and Implications. Academy of Management Review, 20(1), 65-91. https://doi.org 10.5465/Amr.1995.9503271992

Dowling, J., \& Pfeffer, J. (1975). Organizational legitimacy: Social values and organizational behaviour. Pacific Sociological Review, 18(1), 122 - 126. https://doi.org 10.2307/1388226

Eisenhardt, K. M. (1989). Agency theory: An assessment and review. Academy of Management Review, 14(1), 57-74. http://www.jstor.org/stable/258191

Firth, M., Wong, S. M., \& Yang, Y. (2014). The double-edged sword of CEO/chairperson duality in corporatized state-owned firms: evidence from top management turnover in China. Journal of Management \& Governance, 18(1), 207-244. https://doi.org 10.1016/j.jbusres.2008.10.017

Freeman, R., \& Reed, D. (1983). 'Stockholders and stakeholders: A new perspective on corporate governance'. California Management Review, 25(2), 88 - 106. https://doi.org/10.2307/41165018

Gates, S. K., Lowe, D. J., \& Reckers, P. M. J. (2006). Restoring public confidence in capital markets through auditor rotation. Managerial Auditing Journal, 22(1), 5-17. https://doi.org/10.1108/02686900710715611

Gompers, P., Ishii, J., \& Metrick, A. (2003). Corporate Governance and Equity Prices. Quarterly Journal of Economics, 118(1), 107 - 155. https://doi.org/10.1162/00335530360535162

Good, K. (1994). Corruption and Mismanagement in Botswana: A Best-Case Example? The Journal of Modern African Studies, 32(3), 499-521. http://www.jstor.org/page/info/about/policies/terms.jsp

Haniffa, R. M., \& Cooke, T. E. (2005). The impact of culture and governance on corporate social reporting. Journal of Accounting and Public Policy, 24(5), 391-430. http://dx.doi.org/10.1016/j.jaccpubpol.2005.06.001

Howarth, C. (2012). Audit Firm Rotation, a good or bad proposal? http://www.crowehorwath.net/crowe-horwath-global/insights/insights-assets/audit_firm_rotation_\%E2\%80 $\% 93$ _a_good_or_bad_proposal_.aspx

Jensen, M. C., \& Meckling, M. H. (1976). Theory of the firm: Managerial behaviour, Agency Costs and Ownership Structure. Jourrnal of Financial Economics, 20(1), 305-360. http://dx.doi.org/10.2139/ssrn.94043

Josiah, J., Themba, D., \& Matenge, T. M. (2016). Corporate Governance in Botswana: Exploring Developments and Compliance. Botswana Journal of Business Volume, 9(1) 1-20.

Key, S. (1999). Toward a new theory of the firm: a critique of stakeholder "theory". Management Decision, 37(4), 31-32. https://doi.org/10.1108/00251749910269366

Khonani, O. (2015). BMC Knowingly Exported Doped Beef to EU-Court Records. Fond at: http://www.sundaystandard.info/bmc-knowingly-exported-doped-beef-eu-court-records

Lang, M., \& Lundholm, R. (1993). Cross-Sectional Determinants of Analyst Ratings of Corporate Disclosures. Journal of Accounting Research, 31(2), 246-271. https://doi.org 10.2307/2491273 
Li, S., Lin, Y. C., \& Selover, D. D. (2014). Chinese State-Owned Enterprises: Are They Inefficient? Chinese Economy, 47(5-6), 81-115. https://doi.org 10.2753/CES1097-1475470504

Lindblom, C. K. (1994). The implications of organizational legitimacy for corporate social performance and disclosure. Critical Perspectives on Accounting Conference, New York, NY.

Magang, T. I. (2012). Culture and Corporate Governace in South Africa. (PhD). University of Bradford. https://books.google.co.bw/books/about/Culture_and_Corporate_Governance_in_Sout.html?id=6ODxlgEA CAAJ\&redir_esc $=\mathrm{y}$

Magang, T. I., \& Magang, V. G. (2016). Corporate Governance and Compliance in Botswana: Issues and Challenges. Journal of Research in Business, Economics and Management (JRBEM), 7(1), 1041-1061. https://doi.org 10.5430/bmr.v6n4p64

Mangena, M., \& Chamisa, E. (2008). Corporate governance and incidences of listing suspensions by the JSE Securities Exchange of South Africa: An empirical analysis. The International Journal of Accounting, 43(1), 28-44. https://doi.org/10.1016/j.intacc.2008.01.002

Mayer, R. C., Davis, J. H., \& Schoorman, F. D. (1995). An Integrative Model of Organizational Trust. The Academy of Management Review, 20(3), 709-734. https://doi.org 10.2307/258792

McGregor, L. (2011). Corporate governance in South Africa. Handbook on International Corporate Governance: Country Analyses edited by Christine A. Mallim. Chapter 18. Edward Elgar Publishing.

McKinnon, J., \& Dalimunthe, L. (1993). Voluntary disclosure of segment information by Australian diversified companies. Accounting and Finance, 33(1), 33-50. https://doi.org/10.1111/j.1467-629X.1993.tb00192.x

Munisi, G., Hermes, N., \& Randøy, T. (2014). Corporate boards and ownership structure: Evidence from Sub-Saharan Africa. International Business Review, 23(4), 785-796. http://dx.doi.org/10.1016/j.ibusrev.2013.12.001

Ncube, F., \& Maunganidze, L. (2014). Corporate Governance and Executive Compensation in Zimbabwean State Owned Enterprises: A Case of Institutionalized Predation. Management, 4(6), 131-140. https://doi.org/10.5923/j.mm.20140406.01

Neimark, M. K. (1992). The hidden dimensions of annual reports: sixty years of social conflict at General Motors. New York: Markus Wiener Pub.

Noreen, E. (1988). The economics of ethics: A new perspective on agency theory. Accounting, Organizations and Society, 13(4), 359-369. https://EconPapers.repec.org/RePEc:eee:aosoci:v:13:y:1988:i:4:p:359-369

Ntim, C. G., Opong, K. K., Danbolt, J., \& Thomas, D. A. (2012). Voluntary corporate governance disclosures by post-Apartheid South African corporations. Journal of Applied Accounting Research, 13(2), 122-144. https://doi.org/10.1108/09675421211254830

Okeahalam, C. C. (2004). Corporate governance and disclosure in Africa: Issues and challenges. Journal of Financial Regulation and Compliance, 12(4), 359-370. https://doi.org/10.1108/13581980410810902

Ponnu, C. H. (2008). Corporate governance structures and the performance of Malaysian public listed companies. International Review of Business Research Papers, 4(2), 217-230.

Pozen, R. (2012). Mandatory audit rotation risks putweigh benefits. http://economia.icaew.com/opinion/robert-pozen-mandatory-audit-rotation

Ross, S. (1973). The Economic Theory of Agency: The Principal's Problem. American Economic Review, 63(2), 134-139. https://EconPapers.repec.org/RePEc:aea:aecrev:v:63:y:1973:i:2:p:134-39

Rouf, M. (2011). The relationship between corporate governance and value of the firm in developing countries: Evidence from Bangladesh. The International Journal of Applied Economics and Finance, 5, 237-244. https://doi.org/10.3923/ijaef.2011.237.244

Sari, S. A. (2013). The Impact of Governance Structure to the Effectiveness of the Board in Implementing Good Corporate Governance at Indonesian State-Owned Enterprises. International Business Management, 7(4), 295-305. https://doi.org/10.1177/0972150917692213

Simpson, S. N. Y. (2013). Public Sector Reform and Disclosure Practices of State Owned Enterprises; The Case of Ghana. Found at: http://etheses.bham.ac.uk/4902/1/Simpson14PhD.pdf Accessed: 15th January, 2017. (Doctor of Philosophy), Business School College of Social Sciences University of Birmingham, Birmingham, England. 
Sternberg, E. (1999). The Stakeholder Cocept: A Mistaken Doctrine, Issue Paper No. 4. Retrieved from http://papers.ssrn.com/sol3/papers.cfm?abstract_id=263144

StrØm, K. (2000). Delegation and accountability in parliamentary democracies. European Journal of Political Research, 37(3), 261-289. https://doi.org/10.1111/1475-6765.00519

Sunday Standard Reporter. (2011). Inside The BDC Corruption Money Trail. Found at: http://www.sundaystandard.info/inside-bdc-corruption-money-trail. Accessed: 10th June, 2017, Sunday Standard.

The Institute of Internal Auditors. (2012). Mandatory Audit Firm Rotation Too Costly With Minimal Benefit, Cautions IIA The IIA comments on PCAOB's Concept Release Regarding Auditor Independence and Audit Firm

Rotation.

https://na.theiia.org/news/Pages/Mandatory-Audit-Firm-Rotation-Too-Costly-With-Minimal-Benefit-Cautio ns-IIA.aspx

Van Slyke, D. M. (2007). Agents or Stewards: Using Theory to Understand the Government-Nonprofit Social Service Contracting Relationship. Journal of Public Administration Research and Theory, 17(2), 157-187. https://doi.org/10.1093/jopart/mul012

Watts, R. I., \& Zimmermann, J. L. (1978). 'Towards a Positive Theory of the Determination of Accounting Standards'. The Accounting Review, 53(1), 112-134. http://repository.upenn.edu/sire/41

Zeng, S., Xu, X., Dong, Z., \& Tam, V. W. (2010). Towards corporate environmental information disclosure: an empirical study in China. Journal of Cleaner Production, 18(12), 1142-1148. https://doi.org/10.1108/MD-08-2014-0515

\section{Notes}

Note 1. It is common practice for SOEs in Botswana to ask for bail out funding from the central government whenever they are cash strapped. For instance between 2010 and 2011, cash strapped Botswana Power Corporation (power utility) received P2 billion from government to sustain the corporation (Botswana Guardian Reporter, 2013). Other SOEs have also knocked on the government's door step for similar rescue packages such as Water Utilities Corporation, Air Botswana, Botswana Meat Commission, Botswana Examination Council, Botswana National Sports Council (Sunday Standard Reporter, 2016).

Note 2. Opinion writers have castigated the Botswana Parliament Public Accounts Committee for being "a memento whose only role is to criticize hapless accounting officers on certain expenditures without powers to impose sanctions on wayward ministries and departments" (Dipholo, 2016, THE PUBLIC ACCOUNTS COMMITTEE IS AS HOPELESS AND PRETENTIOUS AS PARLIAMENT, SUNDAY STANDARD, 13 JULY, 2015).

Note 3. National Development Bank was established under an act of parliament in 1963.The Bank is owned by the Government of Botswana and operates under the control of a Board of Directors appointed by the Minister of Finance and Development Planning (NDB Website, 2017). According to Good (1994, p. 509), "the NDB was established 'for the purpose of promoting the economic development of Botswana', and to this end was meant 'to provide financial assistance', and to conduct its business 'in the manner best suited for the efficient and economical utilization of its funds'.

Note 4. Botswana Housing Corporation (BHC) is a parastatal under the Ministry of Lands \& Housing. BHC was established by an Act of Parliament (CAP 74.03) of 1971. BHC's mandate as outlined under section 14 of the BHC Act is to; provide for the housing, office and other building needs of the government and local authorities; provide for and to assist and to make arrangements for other persons to meet the requirements of paragraph and to undertake and carry-out and to make arrangements for other persons to undertake and carry-out building schemes in Botswana.

Note 5. Botswana Development Corporation (BDC) is Botswana's main agency for commercial and industrial development (BDC, 2017). BDC was established in 1970 under the Companies Act, primary mandate is to drive the Industrialisation of the country by providing financial assistance to investors with commercially viable projects (BDC, 2017).

Note 6. Botswana Meat Commission (BMC) was established on the 24th December 1965, by an act of Parliament to promote the development of the country's beef and related products globally (BMC, 2017). 
Note 7. Annual reports for 2010 not available. Total assets calculated for three years. Compliance for the 2010 based on 2009 and 2011 level of compliance.

\section{Appendix}

\section{Appendix A: List of SOEs/Parastatals Included in the Study}

\begin{tabular}{ll}
\hline SOE Names & SOE Name Abbreviation \\
\hline Botswana Agricultural Marketing Board & BAMB \\
Botswana Building Society & BBS \\
Botswana Development Corporation & BDC \\
Botswana Housing Corporation & BHC \\
Botswana Institute of Development Policy Analysis & BIDPA \\
Bank of Botswana & BOB \\
Botswana Post & BP \\
Botswana Power Corporation & BPC \\
Botswana Stock Exchange & BSE \\
Botswana Telecommunications Authority & BTA \\
Botswana Telecommunications Corporations & BTC \\
Citizen Entrepreneurship Development Agency & CEDA \\
Motor Vehicle Accident Fund & MVAF \\
Non-Banking Financial Institutions Regulatory Authority & NBFIRA \\
National Development Bank & NDB \\
Public Procurement and Asset Disposal Board & PPADB \\
\hline
\end{tabular}

Appendix B: South African King Code Checklist

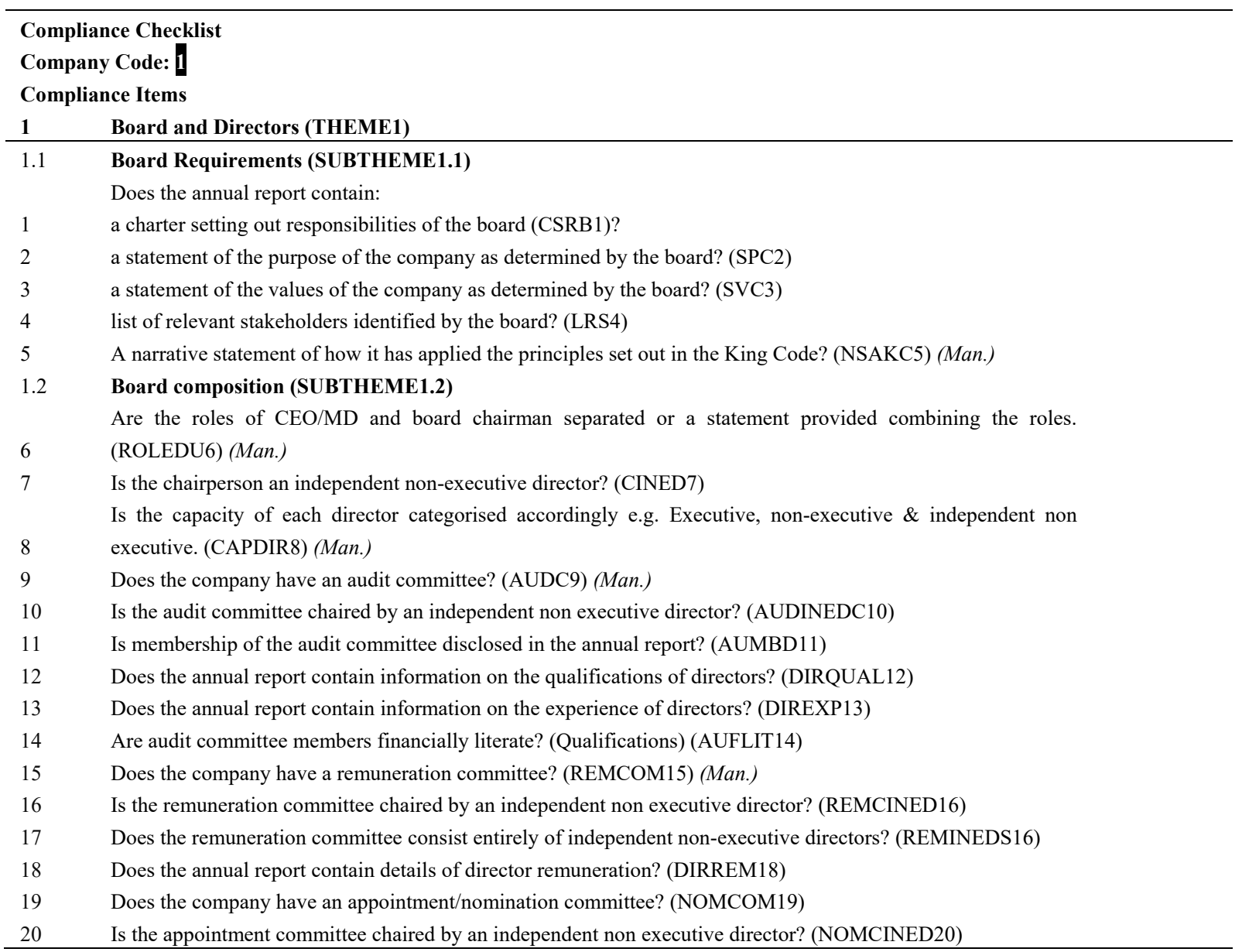




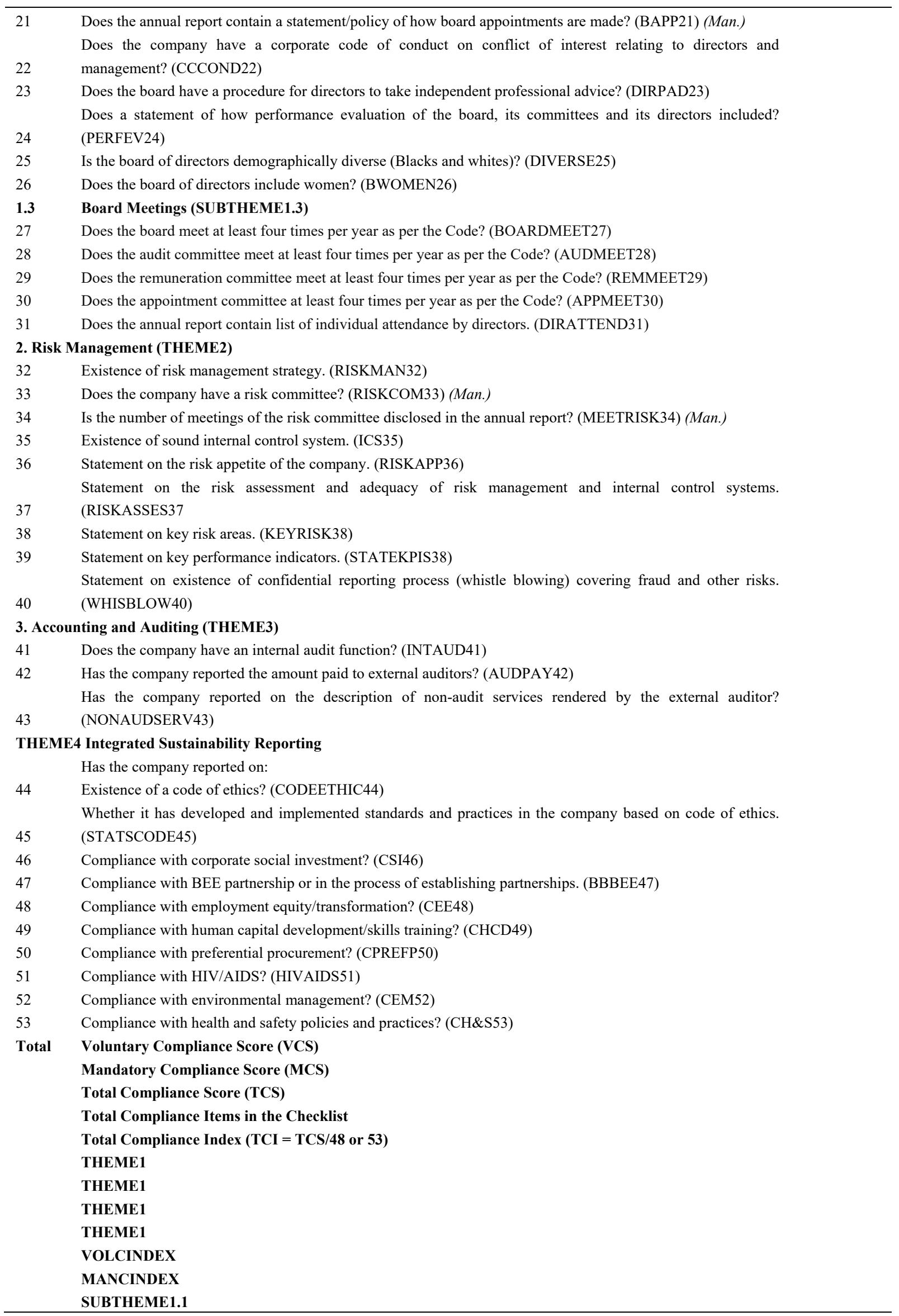




\section{SUBTHEME1.2}

SUBTHEME1.3

Note: Scores may not be assigned to blacked out cells.

\section{Copyrights}

Copyright for this article is retained by the author(s), with first publication rights granted to the journal.

This is an open-access article distributed under the terms and conditions of the Creative Commons Attribution license (http://creativecommons.org/licenses/by/4.0/). 